\title{
Desire as The Harbinger of Good and Evil in Matthew Lewis's 'The
}

\section{Monk'}

\author{
Dr. Aradhana Mukherjee \\ Department of English and Modern European Languages \\ University of Allahabad \\ Allahabad, Uttar Pradesh, India \\ aradhanamukherjee74@gmail.com
}

Desire is a feeling which gives different shades and hues to a human being's personality. It transforms him either as good or bad depending upon how much can a person cope up with his or her feelings. Mathew Lewis's Gothic novel or rather a thriller 'The Monk' is a blend of desire with the narrative structure which has been appreciated by both the readers and the critic regarding the skilful handling of the theme by the author. This has been seconded by Theodore, the personal servant of the protagonist, Raymond in the following lines: "Authorship is a mania to conquer which no reasons are sufficiently strong; and you might as easily persuade me not to love, as I persuade you not to write.” [Lewis 204.]

'The Monk' combine desire with the narrative through love -stories of the chief characters namely Raymond, Agnes, Lorenzo, Antonia, as well as Ambrosio with the seductress Matilda. With the exception of Ambrosio who fails to keep a check on his dormant feelings that gush out with the erotic thrill provided by Matilda, the rest of the characters are young who want to marry and settle down in life as they are in love. The main or the primary narrative is more or less sidelined with the addition of secondary narratives. Some are historical like the 'Tale of the Bleeding Nun', personal memoirs like Leonella, the aunt of Antonia narrating her sister Elvira's marriage with Raymond's stepbrother, poetic like a two 
poems of Theodore and dreams, visions and the reading of palms by the Gypsy who warns Antonia that she faces dangers of which she is unaware signifying the suspense increasing the curosity of the reader. These narratives or distractions are stories that throw light upon the desires of characters even though they have a minor role to play in the novel.

In the story, the narration plays a key role in bringing out desire and to nourish it in such a manner so as to allow it to become very powerful. In order to obtain the friendship of Agnes's brother Lorenzo, despite committing the sin of seducing Agnes as well as to enable to obtain the consent of the brother to marry her, Raymond narrates his saga filled with struggles. How a simple narration is made attractive, when it is given shape by Raymond's relation with Donna Rodolpha, a cunning aunt of Agnes is when he reads to her stories from the romantic novels. He does this to make the aunt agreeable to his niece's love towards him but on the contrary, Rodolpha falls in love with the young man and admits that she loves him.

The well- known incident of the Mirror adorned with strange shapes of spirits coming alive through Matilda's prowess, represents the corrosive aspect of desire present in the narrative. Once pure but now so much corrupted by his evil advisers and once his lover Matilda, he is filled with ecstasy when she showed him the mirror reflecting Antonia who was preparing to bathe. This has been revealed in the following lines: "She was undressing to bathe herself. The long tresses of her hair were already bound up. The amorous monk had full opportunity to observe the voluptuous contours and admirable symmetry of her person ... Though unconscious of being observed, and inbred sense of modesty induced her to veil her charms; and she stood hesitating upon the brink, in the attitude of the Venus de Medicis. At this moment a tame linnet flew towards her, nestled its head between her dress and nibbled them in wanton play. The smiling Antonia strove in vain to shake off the bird, and at length raised her hands to drive it from it delightful harbour." [Lewis, Mathew. The Monk. Oxford, 1998, pp. 268-9.]. Ambrosio after getting his fill is so tied up with his passion that he quickly 
makes up his mind to obtain Antonia as soon as possible whatever it takes to satisfy his heated- up feelings. ' "I yield!' he cried, dashing the mirror upon the ground: 'Matilda, I follow you! Do with me what you will!'” [Lewis, Mathew. The Monk. Oxford, 1998, p. 269.]

In order to boost up the narrative with desire, two kinds of desires have been shown namely desire of positivity and desire of negativity. The novel is a picture of these two kinds of desires in which there is a continuous conflict between these two and where the reader makes a guess that which will dominate in the end. Desire of positivity is always welcome. The objectives present in it are not frowned upon and they can stand the test of time. As Raymond and Agnes are made one by matrimony, they feel satisfied altogether as well as filled with happiness. They represent positive desire which ends in marriage.

On the flip side, Desire of negativity represents an unfulfilled one remaining a stranger to its real objective which as a result cannot achieve results. The violence accompanying does the work of both pushing it in the wrong direction as well as adding unwelcome power. When a negative desire cannot be controlled, it assumes destructive proportions. The worst case scenario is Ambrosio whose unbridled desire leads him to rape and murder his sister Antonia. How his personality was destroyed by the monks has been discussed in the following lines: "In order to break his natural spirit, the monks terrified his young mind, by placing before him all the terrors with which superstition could furnish them." [Lewis, Mathew. The Monk. Oxford, 1998, p. 238.]. They are even emboldened to suppress a trauma suffered by Ambrosio when he was very young. While still a child, he is alienated from his mother and put in the care of the monastery where he is unable to think about his family and the inmates do not let him remember them. The desire to remember his mother chases him for a life time and consequently he never achieves satisfaction.

'The Monk' gives us ample suggestion that Ambrosio's hindered desire stands for the separation of his feelings to achieve his mother. His heart throbs rapidly by seeing a picture 
of the Madonna in front of whom he prays albeit privately in his cell. In an unguarded moment, the Madonna loses her purity as a mother when Ambrosio identifies her as an attractive women in such a way so that his childhood desire turns into an object of lust or sin. He finds a women's breast hard to resist. He is strongly pulled towards the breasts of Matilda and his passion for Antonia achieves gigantic heights when he sees her in the magic mirror. At first, his feelings are tender and more fatherly towards her, but later, he is so enraptured by Antonia's beauty that he forgets his monastic existence and stoops to commit the sin of polluting and murdering the poor girl even forgetting that she is his sister.

The author's main aim to produce this great novel was to show that desire had different forms as well. Theodore is again to the fore. He is represented as the author. He is the sole character whose passion is to become an author as well as to impress his master. His poem 'Love and Age' is an allegorical composition divinely inspired with a tinge of love that heals. Even if the former presents the positive image of love, his latter poem 'The Water King' presents love and desire in a negative light. In this, the protagonist changes his form into a knight so that he can win the hand of a beautiful girl. He takes her with him to his house on a horse but instead of that he causes her death by drowning. The language of the poem is very colourful as it suggests sexual overtones. In the poem, the Water King questions his mother that "How I may yonder maid obtain?" [Lewis, Matthew. The Monk. . Oxford, 1998, p. 284.] As he witnesses her, the world of praise that escape from his lips are: “Oh! Lovely maid, I die for you!” [Lewis, Matthew. The Monk. Oxford, 1998, p. 285.]

Moreover, the Water King's act of courtship and riding with the girl on a horse as well as giving her a watery death, symbolises rape as well as murder. Theodore keeps the language of the poem very subtle as he is reciting this to the Nuns of the Convent who are only allowed to listen very pure forms of poetry and they cannot take liberty out from this. The words 'The Lovely Maid' act as a double- edged sword for Antonia who becomes a 
victim of rape and murder. The gypsy to whom she shows her palm also addresses her as a lovely maid.

In the process of showing that literature consist of desires, good or bad, the poetry of Theodore presents a rudimentary structure of the novel's style of reading and writing; different forms of desire make up the body of the text. 'The Monk' is made up of primary and secondary narratives that continuously disturb the flow of narration making the reader feel that the work itself loves the narrative and the interruptions are created for pleasure and adding variety to the novel.

When we are contemplating about the points where various primary narratives follow each other, a distinctive shape comes out. The wishes of Ambrosio are fulfilled, however, simple they might be but on the other hand, the hopes of the positive characters come to nought. As the story of Ambrosio gets disturbed either by a single or multiple primary narratives, we can see for ourselves that he moves forward to his damnation. For example, when Matilda completely corrupts him at the conclusion of the second chapter, his tale gets disturbed in the coming chapters where Raymond narrates his and Agnes's love story where a break occurs horribly. The narrative leaves Ambrosio behind when his sexual urge gets satisfied. Raymond gets more time to narrate his side of the story in chapters three and four when after sometime a shift takes place in the story to allow Lorenzo to profess his love for Antonia. Even though, the former promises to help the latter in order to escape with his sister, they are still separated from each other. Moreover, the reader is aware of the busting of the plans of Agnes by the monk Ambrosio and consequently the nuns come to know about this leading to Raymond's failure. The reader also notices the dissatisfaction churning within Ambrosio, though his designs are never disturbed. The other characters are satisfied but not till they accomplish their missions and reach towards a good conclusion. 
The narration of Ambrosio is bonded with the plot in accordance with bad desire and so stands different from the common regulations of narrative. The story of Ambrosio like the others is coloured with unfulfilled desire, still it is different as it remains invisible. His narrative is encouraged to progress by frustration, though it makes its move with the help of fulfilment in an ironical manner. Through the medium of unsatisfied desires, the narration of Ambrosio is disturbed when it nears completion. This has been shown through two women Matilda and Antonia. Having his fill with Matilda, "The burst of transport was passed: Ambrosio's lust was satisfied. Pleasure fled, and Shame usurped her seat in his bosom." [Lewis, Matthew. The Monk. Oxford, 1998, p.226.] Later with Antonia, the same treatment was meted out in the following lines: "Scarcely had he succeeded in his design, than he shuddered at himself, and the means by which it was effected."'[Lewis, Matthew. The Monk.Oxford, 1998, p. 368.]

As the tales of the positive characters culminate towards their respective ends, they blend in such a manner so as to turn into a unified narrative. They work through the mode of positive desire resulting in marriage. On the flipside, the desire which propels Ambrosio to move towards the road to destruction is evil and is only meant for annihilation. His stories stands aloof from the others unable to mingle because of its extreme nature. The readers get a proof when the Monk's story is concluded after the marriage ceremonies of the positive characters. He is treated with scorn as well as alienated from the others when pushed to his death by he devil to whom he has sold his soul in order to enjoy the life of immortality and bliss.

Marriage as a beautiful state of heart has been given a prime place by Lewis in his novel 'The Monk' which increases the importance of desire. The novel acts as a plethora of marriages representing positive desires and happy endings. 'The Monk' enquires the viability of various marriages as and when arises the need of possessing good desire, it promotes a 
marriage based on love that defines the feeling on its own. People belonging to the upper and middle classes of the society of England believed that an ideal marriage is that which focussed to fulfil the desires of both the husband and wife. In the words of Lawrence Stone, "Choice [of a spouse in this type of marriage] is made by the children themselves, on the understanding that it will be made from a family of more or less equal financial and status position with the parents retaining the right of veto."'[Stone 271.]

Matthew Gregory Lewis' 'The Monk' possess many parallels with stories from the Bible abounding in morality, still it poses many enquiries regarding the belief of good and evil. Although the author's view brings together many Catholic point of views, the novel sinks into the special relation between God and people. There are many instances where the story brings to light the basic question of sin and its result. Lewis' use of Ambrosio's short comings, his strength and downfalls forges a character that on the whole fails to accept the things he has cherished if ever to nurture hopes of a relief albeit temporary from pain. The narrative's focus on the Satan strengthens the novel by showing his existence through his disciple Matilda but instead of coming out in the open he preferred to remain in the background. Ambrosio's dilemma of choosing his freedom from the current pain which he is experiencing during his trial explores his connection with God who at first give pain but if the sinner asks for mercy does not hesitate to be merciful as well.

The coming of the nineteenth century literature was represented as a period of drastic transformation in values. The rise of Gothic fiction changed how people viewed a person having a faint idea of sexual identity, upbringing within the religious tenets of Christianity and different genders taking up roles within the accepted limits prescribed by the society. Amidst the noteworthy Gothic authors is Mathew Gregory Lewis' who tread the forbidden path while authoring his novel, 'The monk' that has done the work to fascinate the readers even today. Brought up in an environment filled with not so happy memories, Lewis brings to 
light the twisted values of his youth combined with the mysteries of this particular genre of literature. Lewis immersed himself in his work while witnessing the shattering of his family in front of his eyes. However, remaining undeterred, he fulfilled the immediate task of writing this particular novel. Lewis lays bare human being who only cares about the fulfilment of his or her sexual desires devoid of any feeling albeit religious or love. The author represents life through the music created by body where preference of nakedness stands as a symbol of the self running after physical and sexual completeness.

The monk, Ambrosio perceives Lucifer's nude figure after being a witness to Matilda's calling the demon. Matilda, "seized with an excess of delirium”, invoking the evil spirits of Lucifer, tossing "three human figures, and an Agnus Dei", into the "pale sulphurous flame" that rises from the trembling blue fire of the sepulcher. Just as the profanation of the Madonna tears apart religious sanctity, the destruction of the Agnus Dei illustrates the desiccation of Jesus, Lamb of God. The ritual reflects an impure practice of sacrifice as Matilda summons Lucifer through the offering of blood. Matilda, "drawing the poniard from her girdle, plunged it into her left arm. The blood gushed out plentifully; and as she stood on the brink of the circle, she took care that it should fall on the outside. The flames retired from the spot on which the blood was pouring." (Lewis 200). Matilda does not hesitate even to shed blood from her left arm a point very close to her breast. The blood does not only belong to her, as it include the blood of the monk during his active sexual course.

By giving an identity to Ambosio, Lewis sincerely described the monk during his unguarded moments. What started as a discovery of the author's identity very quickly took the form of a narrative that glorified Gothic Literature during the nineteenth century when romanticism was at its zenith due to the works of Wordsworth and Coleridge. Even though Lewis gives his own voice to the narrative, there is something amiss during the conclusion of the novel that makes it authentic and not a mere caricature. All the characters of Lewis are 
individuals during the beginning of the novel but still maintain their own identity till the novel ends. Of all the characters it is Antonia who remains innocent from the beginning till the end. She does not commit any crime even if her personality in this regard by the monk who rapes and does not hesitate to murder her with Matilda's help. The monk's illegitimate sexual encounters fill the reader with disgust which is constantly increased to a crescendo by his consent to nullify the identity and murdering innocent women. In spite of all the negative feelings aroused by the monk, the reader's sympathies are transferred towards Antonia as she is a true child of nature who does not have any hatred towards her persecutor even if it is momentary. 


\section{Bibliography}

Lewis, Mathew. The Monk. Oxford, 1998, p. 200.

-------. The Monk. Oxford, 1998, p. 204.

----------. The Monk.. Oxford, 1998, p. 226.

---------. The Monk. Oxford, 1998, p. 238.

The Monk. Oxford, 1998, pp. 268-9.

The Monk. Oxford, 1998, p. 269.

-. The Monk. Oxford, 1998, p. 284.

----------. The Monk. Oxford, 1998, p. 285.

---------. The Monk. Oxford, 1998, p. 368.

Stone, Lawrence. The Family, Sex and Marriage in England 1500-1800.Harper and Row, 1977, p. 271. 